\title{
The Role of Economic Growth and Spatial Effects in Poverty in Northern Hungary
}

The study examines how the recent economic crisis and the related unfavourable economic features affect poverty. As economic crisis is usually associated with many economic and social problems, it tries to determine to what extent it influences poverty. The paper attempts to prove that economic recession contributes not only to the impoverishment of a significant section of society, but also increases the depth of poverty significantly. If the research supports this hypothesis, it is worth examining to what extent one percent economic growth or economic decline can decrease or increase the rate of the poor and the depth of poverty. Besides the effect of economic growth on the given area, the paper also analyses the effect of the economic growth of the neighbouring areas. The initial hypothesis states that the economic growth of the neighbouring regions can also alleviate poverty. As for spatial effects, spatial autocorrelation is examined in the average income level to reveal how the economic growth of the neighbouring areas affects a given region.

The study examines Northern Hungary, one of the most backward regions in Hungary (based on GDP per capita). Eurostat (2010) reports this region is among the poorest twenty regions within the European Union (based on GDP per capita PPP, Northern Hungary is the 259th among the 271 regions of the European Union).

\section{Poverty}

There is no exclusive definition for poverty. According to the general definition, one is considered to be poor if (s)he lacks the minimal resources necessary to make ends meet, that is his/her income level falls below a minimal level (Bokor 1987).

Three main concepts of monetary poverty can be distinguished. Absolute concepts of poverty assume that minimum material needs can be defined regardless of space and time. Those who fail to satisfy these minimum needs can be considered poor. The relative conceptions define poverty as living below some relative poverty line (Siposné Nándori 2012). People can be considered to be poor if they fall behind some average wealth level in the society to a certain extent (for example 50, 60 or 70 percent of the mean or median equivalised income level). The other approach of the relative poverty concept defines poverty threshold as an income level below which a predefined part (10 or $20 \%$ ) of the population lives (Hegedüs and Monostori 2005).

The subjective poverty concept was worked out by two research groups. Van Praag (1971) elaborated the Income Evaluation Question (IEQ) to collect data on subjective wellbeing. Deleeck and his staff defined the so-called Subjective Poverty Line. Subjective poverty concept can be used in two different meanings. On the one hand, poverty can be 
defined by finding out who people consider to be poor. On the other, it can be defined by collecting peoples' beliefs about their own position in the system of inequalities (Spéder 2002).

Besides its monetary definition, multidimensional concepts of poverty can also be defined that take into consideration non-material socio-economic circumstances that can influence well-being. In this sense, deprived is the person who is in an unfavourable position from different aspects. Therefore, handicaps are accumulated. Accumulated poverty and social exclusion do not, however, refer to the same phenomena. In the case of accumulated poverty, emphasis is put on the output, namely on the deprivation from certain goods and services. Exclusion, however, primarily concentrates on the process leading to poverty (Havasi 2002). This complex view of poverty is important because more people seem to be affected by deprivation if more socio-economic dimensions are taken into consideration rather than defining poverty only by the income level (Bokor 1987).

The European Union elaborated the system of Laeken indicators in 2001, which defines different - mainly relative - measures of poverty. Its application makes it possible to compare different level NUTS regions. The study uses the most common measure of poverty defined by the EU for the calculation: the 60 percent of the median equivalised income.

Provided that the poverty threshold is defined, the most important measures of poverty can be calculated. The most common measure is the poverty rate or headcount index $(\mathrm{H})$ that expresses the ratio of those living below the poverty line within the population (Ravallion 1996).

$$
H=\frac{p}{n},
$$

where $p$ is the number of persons living below the poverty threshold and $n$ is the number of population. This measure describes the extent of poverty. However, it does not provide any information about the depth of poverty. When the financial position of a poor person worsens, the value of the poverty rate will not change at all.

That is why it is also worth computing poverty gap, which measures the distance between the average income of the poor and the poverty threshold. In order to make it comparable over time and space, this measure can be expressed as a percentage of the poverty threshold (this is the so-called poverty gap ratio (PG)).

$$
P G=\frac{1}{p} \sum_{i=1}^{p} \frac{g_{i}}{z},
$$

where gi's are the poverty gaps and $z$ is the poverty threshold (Hajdú 1997).

Besides the extent and the depth of poverty, measuring income inequalities is also necessary to get a profound view of poverty. Among other statistics, income inequalities can be measured with the Lorenz-curve or the Gini coefficient.

Sen (1976) postulated two desirable properties of poverty statistics: the monotonicity axiom requires an increase in the poverty level if the income of a poor person decreases while the transfer axiom requires a rise in the value of the poverty measure when a transfer is provided from a poor person to a person with higher income level. The poverty rate $(\mathrm{H})$ meets neither of these axioms, while the poverty gap (PG) violates only the transfer axiom. 
Because of these problems, Sen (1976) elaborated an index of poverty that meets both requirements:

$$
\mathrm{P}_{\mathrm{S}}=\mathrm{H} \cdot\left[\mathrm{PG}+(1-\mathrm{PG}) \cdot \mathrm{G}_{\mathrm{p}}\right],
$$

where $\mathrm{Gp}$ is the Gini coefficient of the poor persons' income distribution.

\section{The effect of economic growth on poverty}

Economists and sociologists have long been debating the nature of the relationship between economic growth and poverty. There are ambiguities about how economic growth affects the conditions of the poor. If economic growth can significantly reduce poverty, strategies relying on economic growth to reduce poverty are probably justified (Bourguignon 2002).

In the 1970s, many economists argued that economic growth is not enough to reduce poverty. In 1974, Chenerey and his staff (1974) found that growth can make an improvement for only two-thirds of the population. Adelman and Morris (1973) had a similar opinion. They said that economic growth decreased the income level of the poor people in absolute and relative terms. Therefore, those who live in extreme poverty were rather hurt than supported by economic growth. Ravallion (2009) drew the same conclusion. He concluded that the growing advantage of beginning from a lower development level cannot be realised when poverty rate is high.

In the evaluation of the theories about the relationship between poverty and economic growth, Kuznets (1955) hypothesis played a significant role. It says that economic growth and poverty are related in an inverted U-shaped curve. It implies that in the early stages of economic growth, income distribution worsens and it only starts to improve when countries reach middle-income status. At the beginning of economic growth, income inequalities increase, this prevents the improvement of the poor's circumstances. Kuznets did not use any time series, just cross-sectional data and theory for his research. Later, economists started to use time series as well to describe the relationship between economic growth and poverty (similar research was carried out by Ravallion (2009), Deininger and Squire (1996), Brno, Ravallion and Squire (1998)). All of these studies tend to reject the Kuznets hypothesis. Empirical findings showed that economic development does not have any significant impact on income distribution (Adams 2003). Deininger and Squire (1996) found several countries where per capita GDP increased significantly while the value of Gini coefficients hardly changed at all.

Later many new findings appeared that supposed a significant relationship between economic growth and poverty. Dollar and Kray (2001) argued that the average income of the poorest part of society grew proportionately with average incomes. Their statement was based on empirical research using data from 92 countries throughout four decades. Kanbur (1987) claims that after a while - even without redistribution - poor people can cross the poverty line and get out of poverty. In the case of a developing country, however, it takes more than twenty years to be lifted out of poverty. Adams (2003) carried out research based on 50 countries and found that economic development reduced poverty significantly because it has little or no impact on income inequalities.

A research examining Northern Hungary between 2000 and 2007 concluded that economic growth can significantly decrease the poverty rate and poverty gap ratio where poverty was defined based on the existence minimum (Siposné Nándori 2009). This 
research, however, did not take into account the effect of the economic growth of the neighbouring regions, nor controlled for the differences in human development.

On the basis of this study and that of Adams (2003), this paper hypothesises that economic growth can reduce the headcount index, the depth of poverty and the Sen-index of poverty at the same time in Northern Hungary. Moreover, that spatial effects are significant in Northern Hungary, i.e. the economic growth of the surrounding areas can also decrease the headcount index, the poverty gap ratio and the Sen-index.

\section{Applied methods}

First, the study introduces spatial autocorrelation of the per person net income level in the settlements of the Northern Hungarian region. Spatial autocorrelation refers to the degree of dependency among observations in a geographic space. Calculating spatial autocorrelation will reveal whether the average income level of the neighbouring northern Hungarian settlements has an effect on each other or not. Moran's I is one of the spatial autocorrelation statistics. It requires measuring a spatial weight matrix that expresses the intensity of the spatial relationship between neighbouring observations (Kocziszky 2013). The formula for Local Moran's I is as follows:

$$
\mathrm{I}_{\mathrm{i}}=\frac{\left(X_{i}-\bar{X}\right)}{s_{x}^{2}} \cdot \sum_{j=1}^{n}\left[W_{i j} \cdot\left(X_{j}-\bar{X}\right)\right]
$$

where $I$ is the Local Moran's $I$ statistics, $\bar{X}$ is the mean value of the examined variable, $X_{i}$ is the value of the given variable in the $i^{\text {th }}$ settlement, $X_{j}$ is all the values of the given variable belonging to all the settlements except for $i, s_{x}{ }^{2}$ is the variance of all the values of the examined variable, the summation over $j$ indicates that only values of the neighbouring areas are included, and $\mathrm{W}_{\mathrm{ij}}$ is the weights matrix (Tóth 2003). To make the interpretation easier, the weights $\mathrm{W}_{\mathrm{ij}}$ are usually row standardized and $\mathrm{W}_{\mathrm{ii}}=0$ (Anselin 1995).

Local Moran's I is a LISA (local indicator of spatial autocorrelation) statistic (Anselin 1995). Higher Local Moran's I value indicates higher similarity of the given region with its neighbouring regions regarding the examined variable.

Univariate Local Moran's I in Northern Hungary is calculated using GeoDa software (Anselin 2003) and the average per person income level from the database of the National Tax and Customs Administration of Hungary for the 610 settlements (towns and villages) of the region. The weight matrix is calculated by taking into account the five nearest neighbours as this way of creating a weight matrix is possible when the number of cases is more than 600. The number of permutations is 999 to ensure a robust solution. The Local Moran's I is calculated for 2007 and 2012. In this way, it is also possible to reveal if the economic crisis has resulted in any changes in the spatial effects.

The effect of economic growth on poverty can be described with regression analysis. Poverty at country $i$ at time $t$ can be expressed in the following way (Ravallion-Chen 1996):

$$
\mathrm{P}_{\mathrm{it}}=\gamma+\beta \cdot \mu_{\mathrm{it}}+\varepsilon_{\mathrm{it}}-\beta \mathrm{v}_{\mathrm{it}}
$$

where $P$ is a measure of poverty in country $i$ at time $t, \mu_{\mathrm{it}}$ is the measure of economic growth, $\beta$ is the growth elasticity of poverty with respect to the given measure of economic growth, $\gamma$ is a constant, $\varepsilon_{\mathrm{it}}$ is a white noise error term and $\mathrm{v}_{\mathrm{it}}$ is a country-specific error term. This model ignores every other factor that can influence the relationship between economic 
growth and poverty. That is why the following extended form of this model is used in the further analysis:

$$
\lg P_{i t}=\alpha+\beta_{1} \cdot \lg \mu_{\mathrm{it}}+\beta_{2} \cdot \operatorname{lgEDUC} \mathrm{it}_{\mathrm{it}}+\beta_{3} \cdot \operatorname{lgREG}_{\mathrm{it}}+\mathrm{a}_{\mathrm{i}}+\varepsilon_{\mathrm{it}}
$$

where $P$ is the poverty measure (headcount index, poverty gap ratio or Sen-index) in county $i$ at time t. The model contains three explanatory variables: $\mu_{\mathrm{it}}$ as the measure of economic growth (per capita real GDP or per capita real net income), EDUC, the rate of secondary school students in the whole population and REG as the measure of spatial effects (the average level of the GDP of surrounding counties). $\alpha$ is the constant term, $\beta_{1}$ expresses the economic elasticity of poverty; $\beta_{2}$ provides information about the effect of human development on poverty and $\beta_{3}$ provides information about the effect of spatial autocorrelation on poverty. Including REG and EDUC variables in the model makes it possible to control for the different levels of human development and spatial autocorrelation among the counties.

Taking into account the availability of the data, the regression analysis can be carried out for the period 2000-2010 (data for the headcount index are available only from 2003). For this time period, data for the three counties of the Northern Hungarian region (BorsodAbaúj-Zemplén, Heves and Nógrád) are available; therefore, a panel database is used for the analysis. The regression function is first determined using pooled OLS regression. Then the joint significance level of the different group means as a low $p$ value counts against the null hypothesis that the pooled OLS model is adequate, in favour of the fixed effects alternative. Moreover, the Breusch-Pagan test statistics are examined, where a low $p$ value counts against the null hypothesis that the pooled OLS model is adequate, in favour of the random effects alternative. Based on these significances, if necessary, random effect or fixed effect regression is carried out. All the regression analysis is carried out in the Getl program.

Data about income levels are derived from the personal income tax returns of the National Tax and Customs Administration of Hungary. Even if data can include biases (like hidden income or income from the black economy), the analysis is carried out using these data because of the lack of more reliable data sources. These data are used to calculate the poverty measures. Data about the rate of secondary school students are from the database of the Hungarian Central Statistical Office. Data about surrounding counties outside the country are derived from the database of Eurostat and the IMF.

In the analyses, three measures of poverty are used: the headcount index, the poverty gap ratio and the Sen-index. Measuring economic growth is also possible in several ways. Per capita GDP on purchasing power parity or per capita average income/average consumption are usually used to measure economic growth. In poverty analysis, per capita income or per capita consumption are used as a measure of economic growth by Kuznets (1955), Kanbur (1987), Kakwani (1993), Ravallion and Chen (1996), Bourguignon (2002); Per capita real GDP or GNI is used by Cashin (1995), Collier and Dollar (1999), and both measures are used by Adams (2003). These two kinds of measures do not often agree. Differences are the result of the different definitions of the two measures. Average income and average consumption values come from household surveys, so they are usually highly correlated with household expenses. However, per capita GDP and GNI values are derived from national accounts, where household expenses are residuals. So any errors or omitted items in national accounts result in the deviation of household expenses. Measuring 
average income or average consumption can also have different results. People are usually not very keen on talking about their income and they tend to reject answering questions related to their income level. According to a study made at the beginning of $1990 \mathrm{~s}$ in Eastern Europe, average consumption level exceeds average income level in $82 \%$ of the cases (Milanovic 1998). Many economists believe that data derived from national accounts are more accurate than the results of a representative survey, but Daeton (2001) believes that this is without any basis.

In the analysis, real GDP per capita derived from national accounts and per capita real net income levels are used (published by the Hungarian Central Statistical Office) to measure economic growth. The current GDP and income values are compensated for changes in the value of money using the inflation rate to get values that express the real change.

\section{Spatial autocorrelation}

In more than $70 \%$ of the settlements of Northern Hungary, autocorrelation was not significant in 2007. Every fifth settlement can be considered either a hot spot or cold spot (refer to Figures 1 and 2).

Local Moran I in the settlements of Northern Hungary, 2007

Figure 1

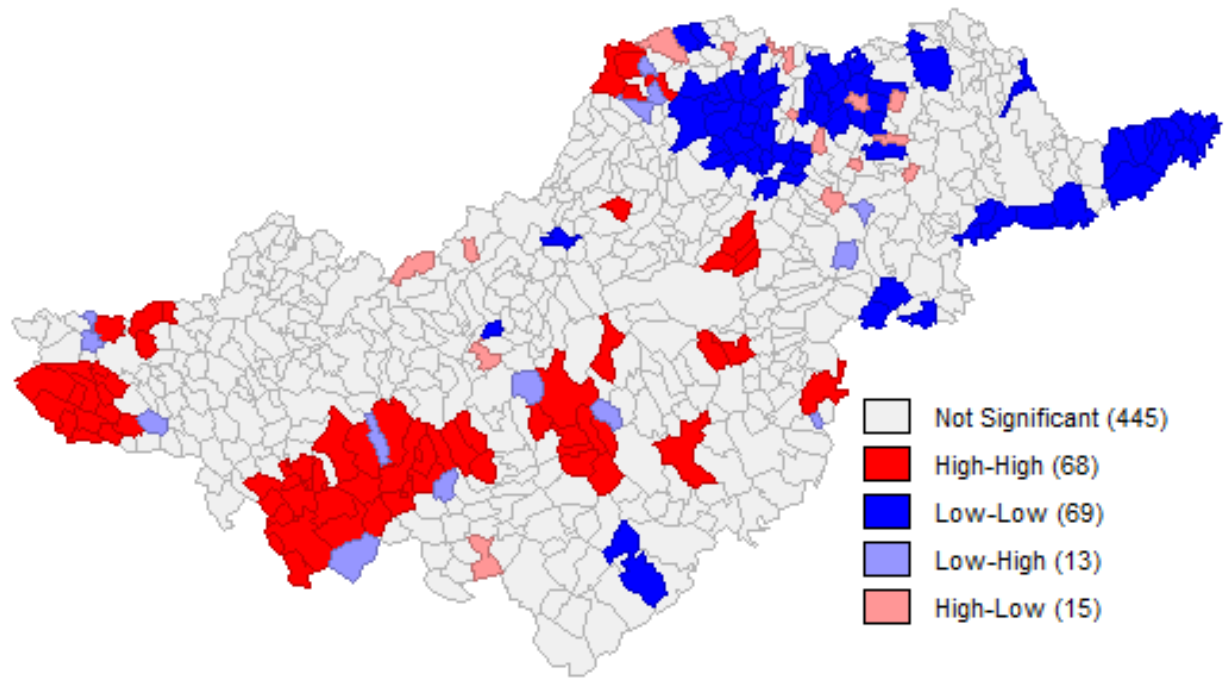

Source: Own compilation. 


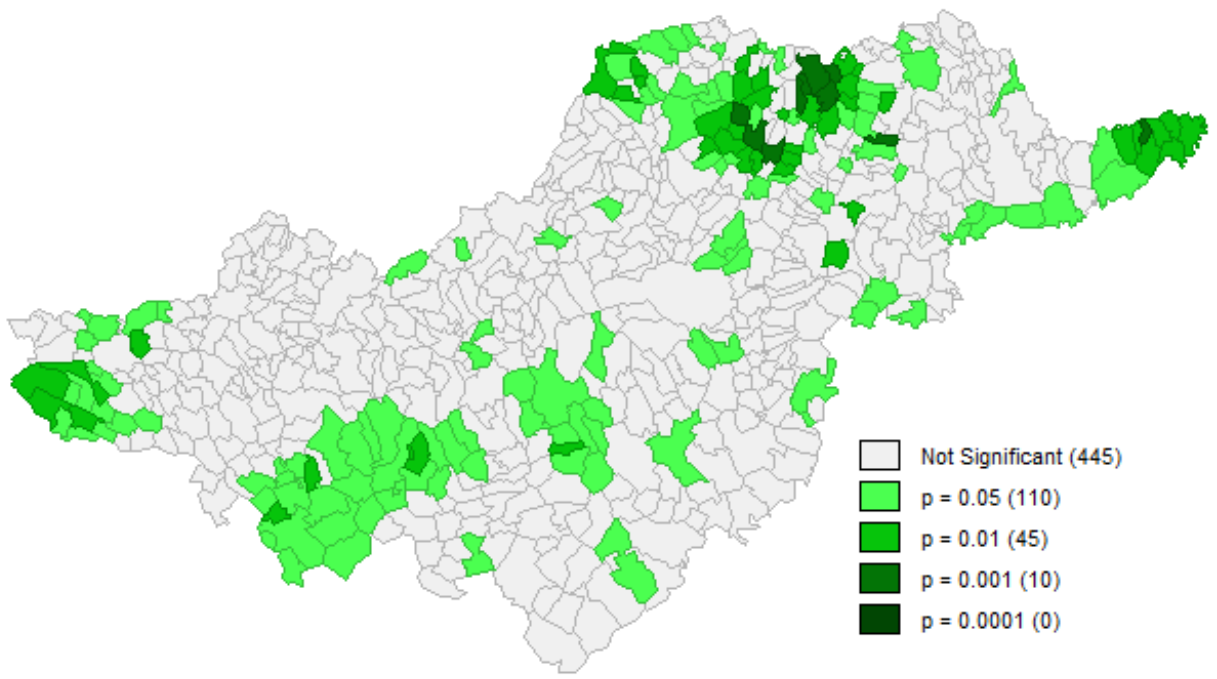

Source: Own compilation.

Hot spots (where settlements with a high-income level are neighboured by settlements with a high-income level) can be found in the Hatvani and Gyöngyösi sub-regions, in the bulk of the Egri (Heves county) and the western part of the Rétsági sub-regions (Nógrád county). Some further small hot spots can also be found in Borsod-Abaúj-Zemplén county (Tiszaújváros, Mezőkeresztes, Bükkaranyos, Nyékládháza, Bükkzsérc, Nagybarca or some settlements northward from Miskolc (Szirmabesenyő, Arnót, Sajópálfala, Sajóvámos) and some others close to the Slovakian border (Aggtelek, Jósvafö, Égerszög, Tornakápolna, Varbóc)).

Out of the 69 cold spots (where settlements with a low-income level are neighboured by settlements with a low-income level), 67 are situated in Borsod-Abaúj-Zemplén county. The majority of the cold spots are situated in the northern and eastern parts of BorsodAbaúj-Zemplén county: in the bulk of the Bodrogközi, Edelényi, Szikszói and Encsi subregions and the southern part of the Sárospataki sub-region. Some further cold spots are isolated in the county: Csobaj, Prügy, Taktakenéz, Alsóregmec, Telkibánya, Abaújvár, Sáta. There are two settlements that belong to the cold spot category in Heves county: Sarud and Fedémes. In Nógrád, there are no cold spots at all.

In $2 \%$ of the settlements, mostly (75\%) situated in the northern part of Borsod-AbaújZemplén county, the average income level is high, while the neighbouring settlements have low-income levels. In another $2 \%$ of the settlements, income level is significantly lower than in the neighbouring settlements. These low-high settlements are distributed evenly in space: five can be found in Borsod-Abaúj-Zemplén, five in Heves and three in Nógrád counties. 


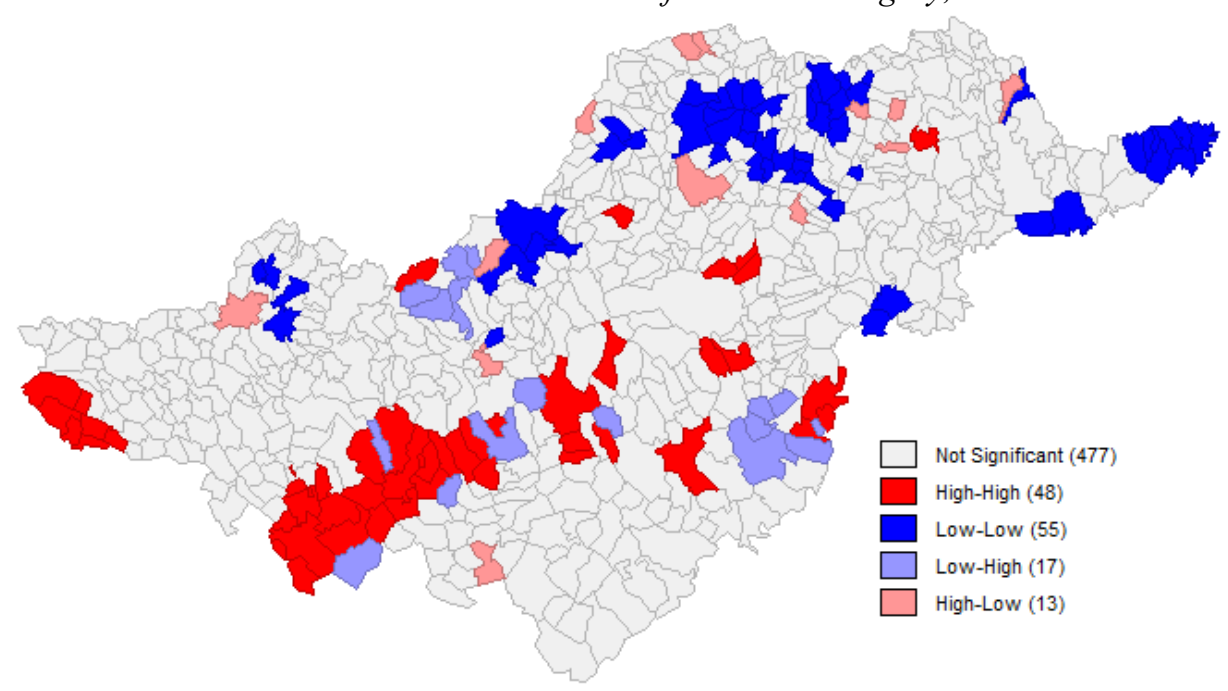

Source: Own compilation.

By 2012, autocorrelation had become not significant in more settlements $(78 \%$ of the settlements) (see Figures 3 and 4). Eight percent of the settlements were hot spots, situated mainly in the western (in the Gyöngyösi and Hatvani sub-regions) and eastern (Egri subregion) parts of Heves county, and in the western part of Nógrád county (in the Rétsági sub-region). Some smaller hot spots could also be found in Borsod-Abaúj-Zemplén county (Mezőkeresztes, Hejőkürt, Tiszapalkonya, Tiszaújváros, Bükkaranyos, Nyékládháza, Szirmabesenyő, Arnót, Sajópálfala, Bükkzsérc, Nagybarca and Mogyoróska).

The bulk of the hot spots remained the same from 2007 to 2012. The bulk of the Gyöngyösi, Hatvani, Rétsági, Egri sub-regions remained a hot spot in the examined period probably due to the closeness of the capital city. The smaller hot spots close to Miskolc (one including Bükkaranyos and Nyékládháza and the other one including Szirmabesenyö, Arnót, Sajópálfala) remained in this position probably due to the closeness of Miskolc. The hot spot of Tiszaújváros grew and included three settlements by 2012, probably due to the increasing influence of the town of Tiszaújváros. 


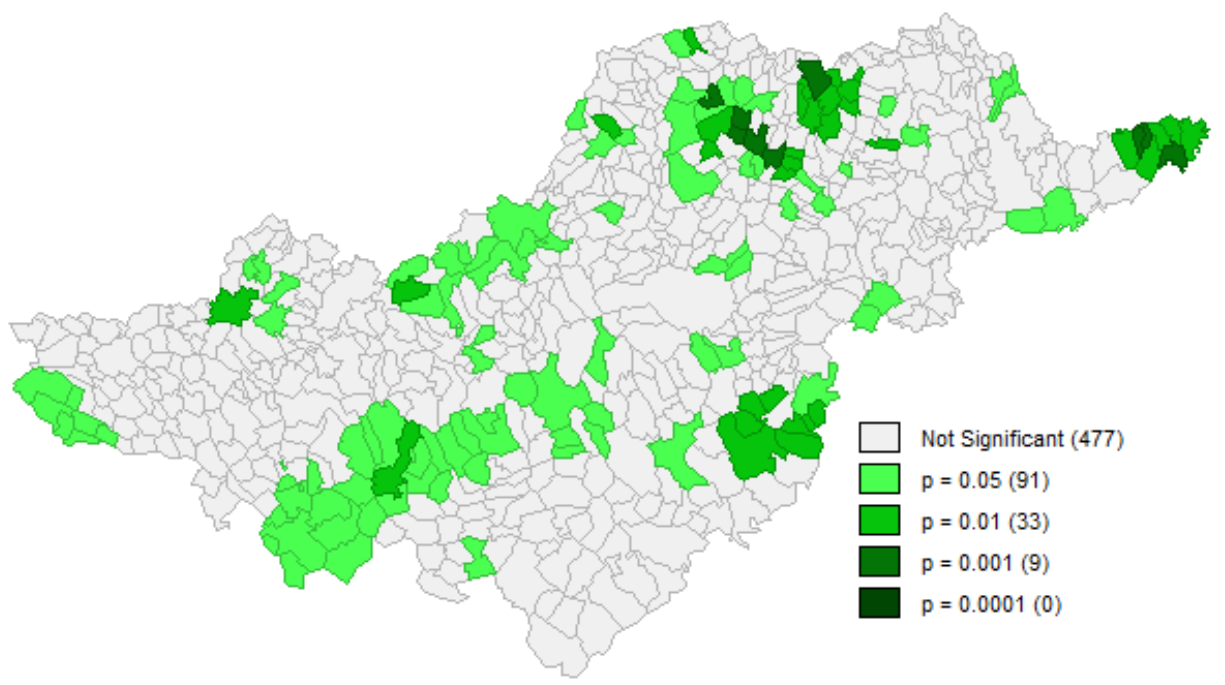

Source: Own compilation

The number of settlements belonging to the cold spot category decreased to a lower extent than the number of hot spots by 2012. The bulk of the cold spots are situated in Borsod-Abaúj-Zemplén county (in the Bodrogközi, Edelényi, Szikszói, Sárospataki, Szerencsi, Ózdi and Encsi sub-regions). A new cold spot with a rather significant extension can be found in the Ózdi sub-region. Some new cold spots (Nógrádmegyer, Karancsság, Piliny and Szécsényfelfalu) can also be found in the northern part of Nógrád county. Fedémes is the only cold spot in Heves county.

\section{Effect of economic growth on poverty}

The parameters of the regression equation can be found in table 1 and 2 . The increase of per capita gross domestic product cannot significantly influence any of the examined poverty measures (Table 1). The results of the regression analysis do not support the initial hypothesis. The economic growth of the neighbouring counties, however, can decrease the headcount index as well as the Sen-index. A one percent economic growth decreases the headcount index by 0.003 percent and the Sen-index by 0.0000246 percent. 
Table 1

The effect of economic growth on poverty statistics in the case of pooled OLS (economic growth is measured with per capita GDP) ( $t$ values are in brackets)

\begin{tabular}{|c|c|c|c|c|c|c|}
\hline \multirow{2}{*}{$\begin{array}{l}\text { Explanatory } \\
\text { variable }\end{array}$} & \multicolumn{6}{|c|}{ Regression coefficient if } \\
\hline & $Y=H$ & $p$ value & $Y=P G$ & $p$ value & $Y=P_{s}$ & $p$ value \\
\hline Constans & $\begin{array}{r}123.32 \\
(9.112)\end{array}$ & 0.06195 & $\begin{array}{l}45.777 \\
(7.484)\end{array}$ & $8.94 * 10^{-7 * * *}$ & $\begin{array}{r}0.407 \\
(7.993)\end{array}$ & $<0.00001^{* * *}$ \\
\hline GDP & $\begin{array}{r}-0,009 \\
(-0.838)\end{array}$ & 0.420 & $\begin{array}{l}0.0006 \\
(0.048)\end{array}$ & 0.963 & $\begin{array}{r}-4.37 * 10^{-5} \\
(-0.519)\end{array}$ & 0.614 \\
\hline EDUC & $\begin{array}{r}-123.098 \\
(-0.509)\end{array}$ & 0.621 & $\begin{array}{l}30.168 \\
(0.113)\end{array}$ & 0.911 & $\begin{array}{r}-1.165 \\
(-0.611)\end{array}$ & 0.554 \\
\hline REG & $\begin{array}{r}-0.003 \\
(-5.936) \\
\end{array}$ & $9.78 * 10^{-5 * * *}$ & $\begin{array}{r}0.0002 \\
(0.448) \\
\end{array}$ & 0.660 & $\begin{array}{r}-2.46^{*} 10^{-5} \\
(-5.447)\end{array}$ & $0.0002^{* * *}$ \\
\hline$\overline{R^{2}}$ & \multicolumn{2}{|r|}{0.81} & \multicolumn{2}{|c|}{0.02} & \multicolumn{2}{|l|}{0.77} \\
\hline Sample size & \multicolumn{2}{|r|}{24} & \multicolumn{2}{|c|}{33} & \multicolumn{2}{|c|}{33} \\
\hline Durbin-Watson & \multicolumn{2}{|c|}{2.13} & \multicolumn{2}{|c|}{2.41} & \multicolumn{2}{|c|}{2.48} \\
\hline F significance & \multicolumn{2}{|c|}{0.316} & \multicolumn{2}{|c|}{0.781} & \multicolumn{2}{|c|}{0.449} \\
\hline $\begin{array}{l}\text { Breusch-Pagan } \\
\text { test significance }\end{array}$ & \multicolumn{2}{|c|}{0.391} & \multicolumn{2}{|c|}{0.211} & \multicolumn{2}{|c|}{0.325} \\
\hline $\begin{array}{l}\text { Fixed or random } \\
\text { effects alternative } \\
\text { model }\end{array}$ & \multicolumn{2}{|r|}{-} & \multicolumn{2}{|c|}{-} & \multicolumn{2}{|c|}{-} \\
\hline
\end{tabular}

Source: Own computation based on the database of the National Tax and Customs Administration of Hungary.

By examining the $\mathrm{F}$ and the Breusch-Pagan test significances, it can be concluded that the pooled OLS models are adequate in all cases, so there is no need to carry out other regression analysis.

When economic growth is measured by per capita real income (Table 2), it has a significant effect on the poverty gap ratio. Surprisingly, this relationship is positive, i.e. a 10 percent increase in economic growth increases the poverty gap ratio by 0.002 percent. It does not support the initial hypothesis either, but the theories that argue that economic growth is useful only to a small part of the society and that the poor are rather hurt than helped by it. Per capita net income level does not have any significant effect on the headcount index and the Sen-index.

The economic growth of the neighbouring counties, however, has a significant effect on all examined poverty measures. A one percent economic growth decreases the headcount index and the poverty gap ratio by 0.003 percent and the Sen-index by 2.6 percent.

The $\mathrm{F}$ and the Breusch-Pagan test significances show that the pooled OLS is adequate in the case of regressions with per capita net income level. 
The effect of economic growth on poverty statistics in the case of pooled OLS (economic growth is measured with per capita net income level) ( $t$ values are in brackets)

\begin{tabular}{|c|c|c|c|c|c|c|}
\hline \multirow{2}{*}{$\begin{array}{l}\text { Explanatory } \\
\text { variable }\end{array}$} & \multicolumn{6}{|c|}{ Regression coefficient if } \\
\hline & $Y=H$ & $p$ value & $Y=P G$ & $p$ value & $Y=P_{s}$ & $p$ value \\
\hline Constans & $\begin{array}{r}61.606 \\
(10.721)\end{array}$ & $<0.00001^{* * *}$ & $\begin{array}{l}54.635 \\
(9.218)\end{array}$ & $<0.00001^{* * *}$ & $\begin{array}{r}0.419 \\
(9.319)\end{array}$ & $<0.00001^{* * *}$ \\
\hline INCOME & $-5.771 * 10^{-}$ & 0.585 & $\begin{array}{r}0.0002 \\
(2.545)\end{array}$ & $0.021^{* *}$ & $\begin{array}{r}8.661 * 10^{-8} \\
(0.108)\end{array}$ & 0.916 \\
\hline EDUC & $\begin{array}{l}-278.47 \\
(-2.865)\end{array}$ & $0.0154^{* *}$ & $\begin{array}{l}-171.35 \\
(-1.549)\end{array}$ & 0.140 & $\begin{array}{r}-2.177 \\
(-2.857)\end{array}$ & $0.016^{* *}$ \\
\hline REG & $\begin{array}{r}-0.003 \\
(-2.900)\end{array}$ & $0.0145^{* *}$ & $\begin{array}{l}-0.003 \\
(9.218)\end{array}$ & $0.0453^{* *}$ & $\begin{array}{r}-2.589 \\
(-3.166)\end{array}$ & $0.009^{* * *}$ \\
\hline$\overline{R^{2}}$ & \multicolumn{2}{|c|}{0.81} & \multicolumn{2}{|c|}{0.30} & \multicolumn{2}{|c|}{0.77} \\
\hline Sample size & \multicolumn{2}{|c|}{24} & \multicolumn{2}{|r|}{33} & \multicolumn{2}{|c|}{33} \\
\hline Durbin-Watson & \multicolumn{2}{|c|}{2.19} & \multicolumn{2}{|c|}{2.80} & \multicolumn{2}{|c|}{2.38} \\
\hline F significance & \multicolumn{2}{|c|}{0.266} & \multicolumn{2}{|c|}{0.409} & \multicolumn{2}{|c|}{0.258} \\
\hline $\begin{array}{l}\text { Breusch-Pagan } \\
\text { test significance }\end{array}$ & \multicolumn{2}{|c|}{0.190} & \multicolumn{2}{|c|}{0.262} & \multicolumn{2}{|c|}{0.232} \\
\hline $\begin{array}{l}\text { Fixed or random } \\
\text { effects alternative } \\
\text { model }\end{array}$ & \multicolumn{2}{|r|}{-} & \multicolumn{2}{|r|}{-} & \multicolumn{2}{|r|}{-} \\
\hline
\end{tabular}

Source: Own computation based on the database of the National Tax and Customs Administration of Hungary.

\section{Summary}

In Northern Hungary, poverty is a big issue, not only in the country, but also in a European context. In the bulk of the northern Hungarian settlements, spatial effects are not significant in economic growth (measured by per person income level). Hot spots can mainly be found in the western part of Nógrád and Heves county while most of the cold spots are situated in Borsod-Abaúj-Zemplén county, mainly in its northern part.

The initial hypothesis about the relationship between economic growth and poverty has to be rejected as neither per capita GDP nor per capita net income level can decrease the examined measures of poverty. Instead, per capita net income level significantly increases the depth of poverty. The initial hypothesis about the relationship between the economic growth of the neighbouring regions and poverty is supported by the current research (the only exception is the effect of per capita GDP on the poverty gap ratio).

The fact that the economic growth of the surrounding areas can decrease the poverty rate and the Sen-index implies that the recent economic recession increases poverty along with many other unfavourable economic and social consequences. It means that the income of an increasing number of people falls below the poverty line, and they become poor. Significant economic growth of the neighbouring areas could play an important role in the poverty alleviation of the Northern Hungarian region. Another interesting result is that economic growth of a given county is currently not enough to reduce poverty. Other means are also necessary to improve the conditions of those living in poverty. This also raises the necessity of state help.

A possible extension of the study in the future is possible with the use of more poverty measures, like income inequalities statistics. This would further increase the reliability of the analysis. 


\section{REFERENCES}

Adams, R. H. Jr. (2003): Economic Growth, Inequality and Poverty Policy Research Working Paper, World Bank, Washington D. C.

Adelman, I.-Morris, C. T. (1973): Economic Growth and Social Equity in Developing Countries Stanford University Press, Stanford.

Anselin, L. (1995): Local indicators of spatial association - LISA Geographical Analysis, 27 (2): 93-115.

Anselin, L. (2003): An Introduction to Spatial Autocorrelation Analysis with GeoDa Spatial Analysis Laboratory, Department of Agricultural and Consumer Economics, University of Illinois, Urbana-Champaign.

Bokor, Á. (1987): Szegénység a mai Magyarországon Magvető Kiadó, Budapest.

Bourguignon, F. (2002): The Growth Elasticity of Poverty Reduction: Explaining Heterogeneity Across Countries and Time Periods Delta Working Paper, Paris.

Bruno, M.-Ravallion, M.-Squire, L. (1998): Equity and Growth in Developing Countries: Old and New Perspectives on the Policy Issues. In.: Vito Tani - Ke-Young Chu (eds.) Income Distribution and High Growth MIT Press, Cambridge, MA.

Cashin, P. (1995): Government Spending, Taxes, and Economic Growth IMF Staff Papers 42 (2) $237-269$.

Chenerey, H.- Ahluwalia, M. et al.(1974): Redistribution with Growth Oxford University Press, New York.

Collier, P.-Dollar, D. (1999): Aid Allocation and Poverty Reduction World Bank, Policy Research Working Paper, 2041, Washington D. C.

Deaton, A. (2010) Price indexes, inequality, and the measurement of world poverty American Economic Review 100 (1): 5-34.

Deininger, K.-Squire, L (1996): A New Data Set Measuring Income Inequality World Bank Economic Review 10 (3): 565-591.

Dollar, D.-Kray, A. (2001): Growth is Good for the Poor World Bank Policy Research Working Paper \# 2587, , World Bank, Washington D.C.

Eurostat (2010): Regional GDP per inhabitant in 2007 Eurostat News Release 25/2010., Luxembourg.

Hajdú, O. (1997): A szegénység mérőszámai KSH Könyvtár és Dokumentációs Szolgálat. Budapest.

Havasi, É. (2002): Szegénység és társadalmi kirekesztettség a mai Magyarországon Szociológiai Szemle 12 (4): 51-71.

Hegedűs, P.-Monostori J. (2005): A szegénység és a társadalmi kirekesztődés méröszámai 2005.Elméleti megalapozás; KSH Népességtudományi Kutató Intézet, Budapest.

Kakwani, N. (1993): Poverty and Economic Growth with Application to Côte d'Ivoire Review of Income and Wealth 39 (2): 121-139.

Kanbur, S. M. R. (1987): Measurement and Alleviation of Poverty: With an Application to the Effects of Macroeconomic Adjustment Staff Paper - International Monetary Fund 34 (1): 60-85.

Kocziszky, Gy. (2013): Térökonometria alkalmazásának lehetőségei a területi kutatásokban Müszaki Földtudományi Közlemények 84 (1): 111-118.

Kuznets, S. (1955). Economic Growth and Income Inequality American Economic Review 45 (1): 1-28.

Milanovic, B. (1998): Income, inequality, and poverty during the transition from planned to market economy World Bank Regional and Sectoral Studies, Washington D. C.

Ravallion, M. (1996): Issues in Measuring and Modeling Poverty World Bank Policy Research Working Paper 1615., Washington D.C.

Ravallion, M. (2009): Why Don't We See Poverty Convergence? World Bank Policy Research Working Paper, 4974., Washington D.C.

Ravallion, M.-Chen, S. (1996): What Can New Survey Data Tell Us about Recent Changes in Distribution and Poverty? World Bank Policy Research Working Paper, 1694., Washington D.C.

Siposné Nándori, E. (2009): Elszegényedés Észak-Magyarországon Észak-Magyarországi Stratégiai Füzetek 6 (2): $68-88$

Siposné Nándori, E. (2012): Spatial econometric analysis of poverty in Northern Hungary between 2000 and 2010 Journal of WEI Business and Economics 1 (1): 81-91.

Spéder, Zs. (2002): A szegénység változó arcai: Tények és értelmezések Andorka Rudolf Társadalomtudományi Társaság; Századvég, Budapest.

Tóth Géza (2003): Területi autokorrelációs vizsgálat a Local Moran I módszerével Tér és Társadalom 17 (4): 39-49. 